\title{
Literature for self-discovery. Looking into adolescence through graphic novels
}

\author{
Literatura per al descobriment personal. Mirar l'adolescència \\ a través de les novel-les gràfiques
}

\author{
Literatura para el descubrimiento personal. Mirar la adolescencia a \\ través de las novelas gráficas
}

\author{
Dalila Forni. Università di Firenze, Italy. dalila.forni@unifi.it. \\ https://orcid.org/0000-0002-1928-3181
}

\begin{abstract}
Graphic novels are an appreciated and popular genre of contemporary children and young adult literature. This art form attracts young readers not only because of the dynamic juxtaposition of words and images, but also because of the complex topics it addresses. Teenagers and young adults see themselves portrayed on the pages of graphic works as they depict real, personal experiences linked to their coming of age. Graphic novels depict young male and female characters who struggle to find their personal path, come to terms with their feelings, and build their identity beyond stereotypes. This literature is particularly complex and captivating as it addresses subjects such as gender, sexuality, friendship, family bonds, social relationships, and various contemporary cultural issues. This paper offers an overview of some graphic novels for young adult readers and explores how they deal with subjects related to identity, self-discovery, and equality. Through a brief analysis of some selected works, the study seeks to compare and investigate how they portray young adults' lives and struggles. The graphic novel stands as a medium which encourages reflection, self-discovery, awareness and empowerment in a liminal and complex phase of adolescence and early adulthood life.
\end{abstract}

Key words: graphic novels, adolescence, identity, education

\section{Resum}

Les novel·les gràfiques són un popular i apreciat gènere de la literatura per a infants i joves contemporània. Aquesta forma d'art atrau joves lectors i lectores, no sols per la juxtaposició dinàmica de paraules i imatges, sinó també per la complexitat dels temes que tracta. Adolescents i joves es veuen reflectits a les pàgines dels treballs gràfics en tant que descriuen experiències reals i personals lligades al seu creixement. Les novel-les gràfiques presenten personatges joves, homes i dones, que lluiten per trobar el seu camí personal, assumir els seus sentiments i construir la seua identitat més enllà dels estereotips. Aquesta literatura és particularment complexa i captivadora en tant que aborda temes com el gènere, la sexualitat, l'amistat, els lligams familiars, les relacions socials i diverses problemàtiques culturals contemporànies. Aquest article ofereix una panoràmica d'algunes novel-les gràfiques per a joves lectors i lectores i explora com tracten temes relacionats amb la identitat, l'autoconeixement i la igualtat. A traves d'una breu anàlisi d'alguns treballs seleccionats, l'estudi tracta de comparar i investigar com retracten la vida i les lluites dels i les joves. 
La novel·la gràfica figura com a un mitjà que encoratja la reflexió, l'autodescobriment, la consciència i l'empoderament en una fase complexa i liminar de l'adolescència i la vida adulta primerenca.

Paraules clau: novel·la gràfica, adolescència, identitat, educació

\section{Resumen}

Las novelas gráficas son un popular y apreciado género de la literatura para la infancia y juventud contemporánea. Esta forma de arte trae a jóvenes lectores y lectoras, no solo por la yuxtaposición dinámica de palabras e imágenes, sino también por la complejidad de los temas que trata. Adolescentes y jóvenes se ven reflejados en las páginas de los trabajos gráficos en tanto que describen experiencias reales y personales ligadas a su crecimiento. Las novelas gráficas presentan personajes jóvenes, hombres y mujeres, que luchan por encontrar su camino personal, asumir sus sentimientos y construir su identidad más allá de los estereotipos. Esta literatura es particularmente compleja y cautivadora en tanto que aborda temas como el género, la sexualidad, la amistad, los lazos familiares, las relaciones sociales y diversas problemáticas culturales contemporáneas. Este artículo ofrece una panorámica de algunas novelas gráficas para jóvenes lectores y lectoras y explora cómo tratan temas relacionados con la identidad, el autoconocimiento y la igualdad. A través de un breve análisis de algunos trabajos seleccionados, el estudio trata de comparar e investigar cómo retratan la vida y las luchas de los y las jóvenes. La novela gráfica figura como un medio que anima a la reflexión, el autodescubrimiento, la consciencia y el empoderamiento en una fase compleja y liminar de la adolescencia y la vida adulta temprana.

Palabras clave: novela gráfica, adolescencia, identidad, educación

\section{Introduction}

This paper aims to analyse a selection of international graphic novels that deal with different phases of adolescence, from pre-adolescence to young adulthood. A sample of five works published in the last twenty years -Blankets (2002) by Craig Thompson; Forget my name (2012) by Zerocalcare; This one summer (2014) by Jillian and Mariko Tamaki; Blue is the warmest colour (2017) by Julie Maroh and L'Âge des secrets (2019) by Magnhild Winsnes- will be investigated. The selected works offer compelling portrayals of adolescent characters through recurrent images and narrative strands. The works have been selected from a plethora of graphic narratives for young audiences for different reasons. Firstly, they are significant examples of this literary genre, as they clearly express typical strategies used by authors and illustrators of graphic novels, establishing a modern literary canon (Calabrese, 2017). Secondly, these books are stylistically different from each other although they share a common interest in portraying adolescent identity with a realistic approach. Thirdly, they are popular works, translated into several languages, and were at the focus of different academic analysis (Stevens, 2010; Calabrese, 2017; Greco, 2019; Stefanelli, 2020). Building on previous studies on pedagogy (Dallari \& Fanrè, 1977; Detti, 1984; Marrone, 2005), literary theory and comic studies (McCloud, 1993; 
Eisner, 2000; Calabrese, 2017), the article explores recurrent literary trends in representing adolescence through a modern multi-layered form of storytelling.

\section{Discovering graphic novels}

Today young adult literature is an extremely wide and complex field that presents different forms of narration based on different techniques, methods, and art forms (Barsotti \& Cantatore, 2019; Trisciuzzi, 2017; Forni, 2020b). Among the most popular and contemporary literary genres, the graphic novel stands out for its recent but exponential success that reinstated the value of comics in the public sphere (Calabrese, 2017, 7). The graphic novel is strictly related to the comic form, which constitutes the overarching form, but gives this medium new narrative possibility. The graphic novel is usually a self-conclusive work that outlines a precise story as a novel usually does. At the same time, it draws on the canons and techniques of comics in terms of format (they both develop a sequential storytelling) but rejects its serialisation. Thus, comics and graphic novels share the same code, based on the juxtaposition of visual and textual media and on the connection of artistic and literary devices (Eisner, 2000, 8; Trisciuzzi, 2017).

Calabrese offers a complete study on the graphic novel and its technical, aesthetic and thematic aspects. He draws on different academic fields, from history to literary theory so as to analyse visual and textual aspects of the graphic novel, define it and highlight its historical contrast with the comic:

\footnotetext{
The term 'graphic novel' was created in order to differentiate a new textual form from the less complex 'comics' -in other words, short, naïve narratives intended mostly for an adolescent audience- presenting itself as a literary form oriented towards a more adult audience, with a different narrative focus and more articulated editorial practices. [...] A graphic novel is a figurative book that tells a long story or many short stories, in a sequential or self-contained way, respecting the conventions typical of comics or conveying autobiographical, historical, journalistic cases (Calabrese, 2017, 8).
}

The relation of the two codes employed in graphic novels, that is words and images, is particularly compelling. On the one hand, as underlined by Eisner "comics communicate in a language that relies on visual experience common to both creator and audience. Modern readers can be expected to have an easy understanding of the image-word mix and the traditional deciphering of text" $(2000,7)$. On the other hand, this interconnection does not necessarily simplify the reading, but in some cases renders it even more complex: 
[...] both linguistic components are constructed and used not to cover the whole semantic space on their own, but to serve a dialectic relationship whereby the language that comes out of it, far from being the simple sum or juxtaposition of the written word and the image, is a communicative expression structurally and semiotically new and different from the other two (Dallari \& Farnè, 1977, 92) ${ }^{1}$.

Thus, the graphic novel is a hybrid literature that exploits the potential of different literary means, positioning itself as an extremely popular medium characterized by narrative and visual complexity. Dal Lago and Giordano highlight the importance of considering the comic as an art form that deserves a different critical approach because of its specific, particular language: "[...] comics not only have the same status as 'real' art, but happily combine words and images, like poetry and music in opera [...] they create a new language, placing themselves among the most important experiments of modern art" $(2006,228) 2$. Similarly, McCloud underscores the potential of those narratives based on the interconnection of words and images, such as comics, although this code is usually perceived as a simplistic "product of crass commercialism" $(1993,140)$.

In their study, Dallari and Farnè discuss the didactic and educational implications of comics (and, we could argue, of its most recent evolution in graphic novels); they also express the prejudice commonly held by school authorities against comics: "It was said that, since comics told a story, giving both the Thus, the graphic novel is a hybrid literature that exploits the potential of different literary means, positioning itself as an extremely popular medium characterized by narrative and visual complexity image and the word, the total confusion of the user was guaranteed, since no mental effort was required to intellectually complete the message" ${ }^{3}(1977,14-15)$. Although some prejudice survives to date, comics and their derivatives can be a source of great learning, thanks to the synergy of images and words,

\footnotetext{
${ }^{1}$ Original Italian text: “[...] entrambe le componenti linguistiche sono costruite e usate non per coprire ognuna per proprio conto tutto lo spazio semantico, ma in funzione di un rapporto dialettico per cui il linguaggio che ne esce lungi da essere la semplice somma o accostamento della parola scritta e dell'immagine, è un'espressione comunicativa strutturalmente e semiologicamente nuova e diversa dalle altre due".

${ }^{2}$ Original Italian text: “[...] il fumetto non solo ha la stessa dignità dell'arte 'vera', ma coniuga felicemente parole e immagini, come la poesia e la musica nell'opera lirica [...] crea un linguaggio nuovo, collocandosi tra le più importanti sperimentazioni dell'arte moderna".

${ }^{3}$ Original Italian text: "Si diceva cioè che, poiché il racconto a fumetti narrava una storia, dando contemporaneamente l'immagine e la parola, era garantito il totale rimbecillimento del fruitore, dal momento che non gli veniva richiesto nessuno sforzo mentale per completare intellettualmente il messaggio".
} 
which works on different linguistic, semiotic and aesthetic levels and offers different interpretative cues (Dallari \& Farnè, 1977; Detti, 1984; Marone, 2005). Like other literary genres, comics and graphic novels also demonstrate an interesting potential for indirect

The stories we read or listen construct our perception of the real world and foster specific values, ideas, archetypes and schemas. Graphic novels, too, can informally educate and help readers reflect on different topics related to adolescence, drawing on collective imaginary. learning, assisting the formation of the self through the imagery they convey (Strazzulla, 1977; Faeti, 1983; Beseghi, 2017). Fiction -from literature to other media- is a narrative form that builds collective imaginary. The stories we read or listen construct our perception of the real world and foster specific values, ideas, archetypes and schemas. Graphic novels, too, can informally educate and help readers reflect on different topics related to adolescence, drawing on collective imaginary. Recently, this art form has become the focus of several academic studies that demonstrate the graphic novel's literary, iconographic and thematic depth, making it equal to 'traditional' narrative forms such as the novel (McCloud, 1993; Stein \& Thon, 2013; Calabrese, 2017; Garrison, 2020).

\section{Graphic novels on and for adolescents}

In general, graphic novels deal with current issues and directly address young readers' daily experiences and highlight fears, problems, dreams, feelings and perceptions of their own identities. In the sixties, coming of age became a key theme in young adult literature; books portraying adolescence conveyed authentic, real, complex experiences, providing indirect support to teen or young adult readers (Garrison, 2020). In particular, graphic novels

[...] offer young adults a unique and provocative perspective, with the combination of illustrations and text telling the story with art and symbols. The focus on visual literacy and symbolism also serves to address diverse learning and reading styles and preferences for young adults, and graphic novels offer clear connections to important curricula and standards (Garrison, 2020, 10).

Furthermore, Calabrese defines this genre as faction, referring to those narratives as a meeting point between fiction, or fictional universes, and facts, the real, everyday life $(2017,11)$. Drawing on the immediacy of comics and the narrative depth of the novel, the graphic novel manages to critically deal with contemporary, complex issues, addressing the reader directly and graphically, reporting their life experiences so as to offer stimulating readings, full of reflections and able to arouse empathetic participation and, above all, identification (Baetens \& Frey, 2014, 11). Readers -despite their age- 
might find themselves depicted on the pages of many graphic novels and might see, among balloons, gutters, and illustrations, life stories similar to theirs; thus, graphic novels might open up new possibilities for readers to reach self-awareness.

According to Rudine Sims Bishop (1990), books are like mirrors that reflect our image, encouraging us to observe it from an external point of view; they are like windows opening onto the world that allow us to have new life experiences. Literature, and specifically graphic novels, widens the perception of young readers and gives them experiences that, even if imaginary, have an impact on their understanding of what surrounds them (Beseghi, 2017). Literature, therefore, is a departure point of encounter and growth, an instrument of mediation, communication, personal exchange. In particular, images constitute a universal and direct language, both semantic and emotional, and surely immediate in its reception (Nodelman, 1990, 5-6): a means of communication that critically welcomes the "society of the homo videns" (Cambi, 2019, 126).

The literary process described by Bishop is of fundamental formative importance during delicate phases of life such as pre-adolescence, adolescence and postadolescence or young adulthood (Mancaniello, 2018; Barone, 2009). These are particularly different and difficult years of both physical and psychological transformation which may lead to continuous conflicts with others and with one's own self. Adolescence and young adulthood constitute a transition period when one searches for oneself, for one's own identity, years of incessant experimentation and desire to reach self-awareness. Contemporary graphic novels attempt to capture the dilemmas,

Contemporary graphic novels attempt to capture the dilemmas, changes and feelings that stand at the basis of the period generically called adolescence. They offer young readers a chance for entertainment, but also a means of indirect training and reflection changes and feelings that stand at the basis of the period generically called adolescence. They offer young readers a chance for entertainment, but also a means of indirect training and reflection. Observing the fictional characters, readers have the opportunity to explore, at least in part, the complexity that characterizes their evolving identity. By reading these pages, it is possible to know each other intimately; see oneself reflected or examined through a fresh perspective; catch new glimpses of the changes that take place in teenagers' lives, unmasking intimate problems and collective fears (Garrison, 2020).

\section{A comparative analysis of five graphic novels}

The analysis of contemporary graphic novels, and in particular of those dealing with adolescence or young adulthood, requires a large and complex study given the amount of works on the subject published in recent years across the world. Graphic novels, part of a flourishing market, are opening 
up new thematic and graphic paths in literature. In order to understand how graphic novels portray adolescence, it is necessary to highlight some recurrent thematic motifs so as to gain insights into the issues they frequently address. Certainly, it is possible to discover some elements that recur, albeit through very different literary and visual strategies, in most of the works on the subject of adolescence.

This article presents a comparative analysis of five works on the theme of adolescence: Blankets (2002) by Craig Thompson; Forget my name (2012) by Zerocalcare; This one summer (2014) by Jillian and Mariko Tamaki; Blue is the warmest colour (2017) by Julie Maroh and L'Âge des secrets (2019) by Magnhild Winsnes. These five graphic novels deal with pre-adolescence, adolescence and young adulthood through the use of different visual and literary strategies, narrative strands and artistic styles.

To begin with, it is necessary to outline the main plot of the selected works. Successively, the article will move onto investigating the main themes and strategies. First, This one summer, by Canadian American Jillian and Mariko Tamaki, was published in 2014, and won the Caldecott Honor in 2015. It tells the story of Windy and Rose, two preadolescents who spend every summer together ever since they were little girls. The story shows how this summer is particularly different for both of them: the girls are growing up, but they are proceeding to maturation in a totally different way. For this reason, it is increasingly difficult to find moments of encounter and friendly confrontation (Abbot \& Tarbox, 2017, 191-204).

Secondly, L'Âge des secrets, published in 2019, is a graphic novel by the Norwegian artist Magnhild Winsnes. The work could be easily compared with the previous book, This one summer, as they both share some key topics, although they employ different artistic devices. L'Âge des secrets tells the story of two young preadolescents, Hanna and Siv, two friends and cousins that are used to spending the summer together. However, this particular summer seems to be different as they are both growing up and are now experiencing new emotions, wishes, and desires. Hanna and Siv's personalities evolve, but in a different way, and they fail to keep their long-lasting friendship.

The third work examined here is Blankets by the American author Craig Thompson, published in 2002. The graphic novel, winner of the 2004 Eisner Awards as Best Graphic Album and Best Writer/Artist, is a famous autobiographical work in which the life of the protagonist, Craig, is told in first-person, from childhood to adulthood, with particular attention to adolescence and its love stories, doubts, uncertain feelings, and family relationships. The story is set mainly in Michigan and Wisconsin during the 90s.

Blue is the warmest colour, written by the French author Julie Maroh in 2010, has received popular acclaim thanks to its cinematic adaptation, appreciated by critics and known for its themes, including 
female sexuality. The story speaks of two high school girls, Clementine and Emma, and their love story. Emma is an eccentric blue-haired girl, an unscrupulous, self-confident artist, and she is opposed to the younger, inexperienced Clementine who is intimidated by her feelings for Emma. The narration is developed through a particular narrative form: Clementine tells the story in the pages of her diary, read by Emma after Clementine's death.

The last work in the sample Forget my name by Italian Zerocalcare was published in 2012. Zerocalcare is one of the most appreciated Italian author/illustrators as far as graphic novels and comics are concerned. In particular, Forget my name outlines the life-phase that lies between adolescence and young adulthood. Like most of the artist's works, it is directly linked to themes such as work instability, the search for living spaces and a lifestyle of one's own, reflecting on goals not yet achieved, the constant comparison with peers. These topics are generally shared by many people who, despite their age, do not yet feel they entirely fit in adult society. In this graphic novel, the protagonist tries to come to terms with his own roots in order to become more aware of his future and the path he will have to take to reach adulthood.

Despite differences in style, content, life-phases depicted, the selected graphic novels share common issues related to the portrayal of adolescence and young adulthood. Thus, in what follows the paper outlines some recurrent tendencies and subjects, investigated through a comparative approach.

\subsection{Interpersonal relationships}

Relationships appear as one of the main features in the representation of adolescent or postadolescent identity. Family relationships stand out as a primary element, even if they are at times conflictual and difficult: parents and teenagers often look for a meeting point that is not always easy to find, as portrayed in Blankets, where the protagonist has to deal with his family's different perspectives on religion. Furthermore, we should add the relationship with peers, such as friends or best friends, schoolmates, brothers, sisters, cousins, boyfriends or girlfriends. These relationships generally are not depicted as stable, but are rather presented as forever transforming and evolving, undermining emotional or love relationships, most of all during pre-adolescence (This one summer, L'Âge des secrets).

Both This one summer and L'Âge des secrets take up friendship as their central theme: the books mostly portray how long-lasting friendships often change during this difficult period of life when each single identity needs to follow its rhythm, time and find its personal space. In this context, as the two books clearly show, a friend may become a stranger; they further highlight how the process of growing up takes different forms, wrecking childhood friendships. By contrast, Blankets focuses mainly on family relations: among the main themes explored in the book, the work develops the complex relationship 
with the boy's parents and their strict religious education. Moreover, the book presents the protagonist's relationship with his younger brother, usually referred to by the protagonist-narrator through several childhood memories, bringing to light both their bond and the frequency of family misunderstandings. Blankets also presents love relationships: love appears as a fresh personal experiment, an emotion to be understood and experienced, even if preponderant, invasive, and hurtful. In addition, we should not forget negative relationships, such as intense confrontations with peers; for instance, episodes of violence or bullying (Forni, 2020a).

\subsection{Reflection on big issues}

These graphic novels are marked by elements of great reflective depth such as death, faith, and religion. Adolescents and young adults as protagonists feel the need to find their own way with regard to religious beliefs and spirituality: they are young people who want to find meaning in their existence. A key theme developed in Blankets is the matter of faith and religion: Craig, who grew up in an extremely religious family, would like to find his way and understand if he is willing to accept the religious teaching of his parents (Stevens, 2010). In particular, faith is intertwined with love issues: having fallen in love with Raina, Craig does not understand whether or not his desire for the girl is legitimate, whether or not it is compatible with the ideals imposed on him by his parents. The work is therefore a spiritual narrative, but also a physical, loving, sexual storytelling: the first experiences with the girl lead the protagonist to strike a delicate balance between his beliefs and his feelings, setting a new path towards adulthood. Blankets also explores themes such as the discovery of masculinity, bullying, disability, divorce, and school problems.

The meaning of one's own existence becomes the focus of the narratives when the characters have to deal with death, for example the loss of a grandmother, a friend, or an old acquaintance. Death works as a catalyst as it unravels hidden meanings of life: experiencing the loss of a relative or a friend, adolescents perceive the inconsistency of life, its fragilities, its turning points. Death usually forces young protagonists to suddenly grow up, experience adult feelings and take on adult responsibilities. 
For instance, in Forget my name, the literary expedient that activates the narrative is the death of the protagonist's grandmother, a key point in the life of the protagonist that will force him to move onto a new life-phase, that of adulthood. Numerous flashbacks that directly refer to childhood and adolescence are deployed in order to illustrate more vividly the feelings and ideas that characterize

Death works as a catalyst as it unravels hidden meanings of life: experiencing the loss of a relative or a friend, adolescents perceive the inconsistency of life, its fragilities, its turning points. Death usually forces young protagonists to suddenly grow up, experience adult feelings and take on adult responsibilities. the difficulties of entering adulthood, introduced by a traumatic event such as the loss of a relative that played a key role during the character's childhood. Through death, childhood is metaphorically broken and has to end: the vacuity of life forces the protagonist to face adulthood. In Blue is the warmest colour death is a central topic and the catalyst for the narration as well: characters have to deal with the protagonist's death right from the very beginning.

\subsection{Gender, sexuality and bodies}

Many of these graphic novels deal with identity issues related to gender and sexuality: the boys and girls represented are characters in the process of becoming someone, characters seeking their own place in the world in terms of gender (Beseghi, 1987; Garrison, 2020, 12). These characters, therefore, often play with gender norms, experiment and try to understand what is culturally allowed, what is appropriate, what needs to be deconstructed so as to allow them to feel comfortable. Teenage characters, in their constant discovery of the Teenage characters, in their constant discovery of the world, offer to young readers new possibilities, new perspectives on gender norms and sexual identity or orientation. Their experimentation with their respective culture allows them to test new points of view and reevaluate or even question longlasting social norms. world, offer to young readers new possibilities, new perspectives on gender norms and sexual identity or orientation. Their experimentation with their respective culture allows them to test new points of view and re-evaluate or even question long-lasting social norms.

Often, graphic novels on adolescence present the theme of the body. This phase of life involves continuous physical changes, and this literature can gently grasp the fear of experiencing bodily change, combined with the desire to find one's own style, one's own personalised but socially shared concept of beauty. For instance, in This one summer, the two girls are shown as opposites considering their physical appearance: Rose, a few years younger, has a stockier body, black, ruffled hair and playful eyes while Windy looks like a long-limbed, light-haired girl with melancholy eyes. The book faces the discovery of the girls' identities and their femininity, introducing them to a wider context 
where first love interests are represented, and first doubts about their bodies are accurately portrayed (Figure 1).

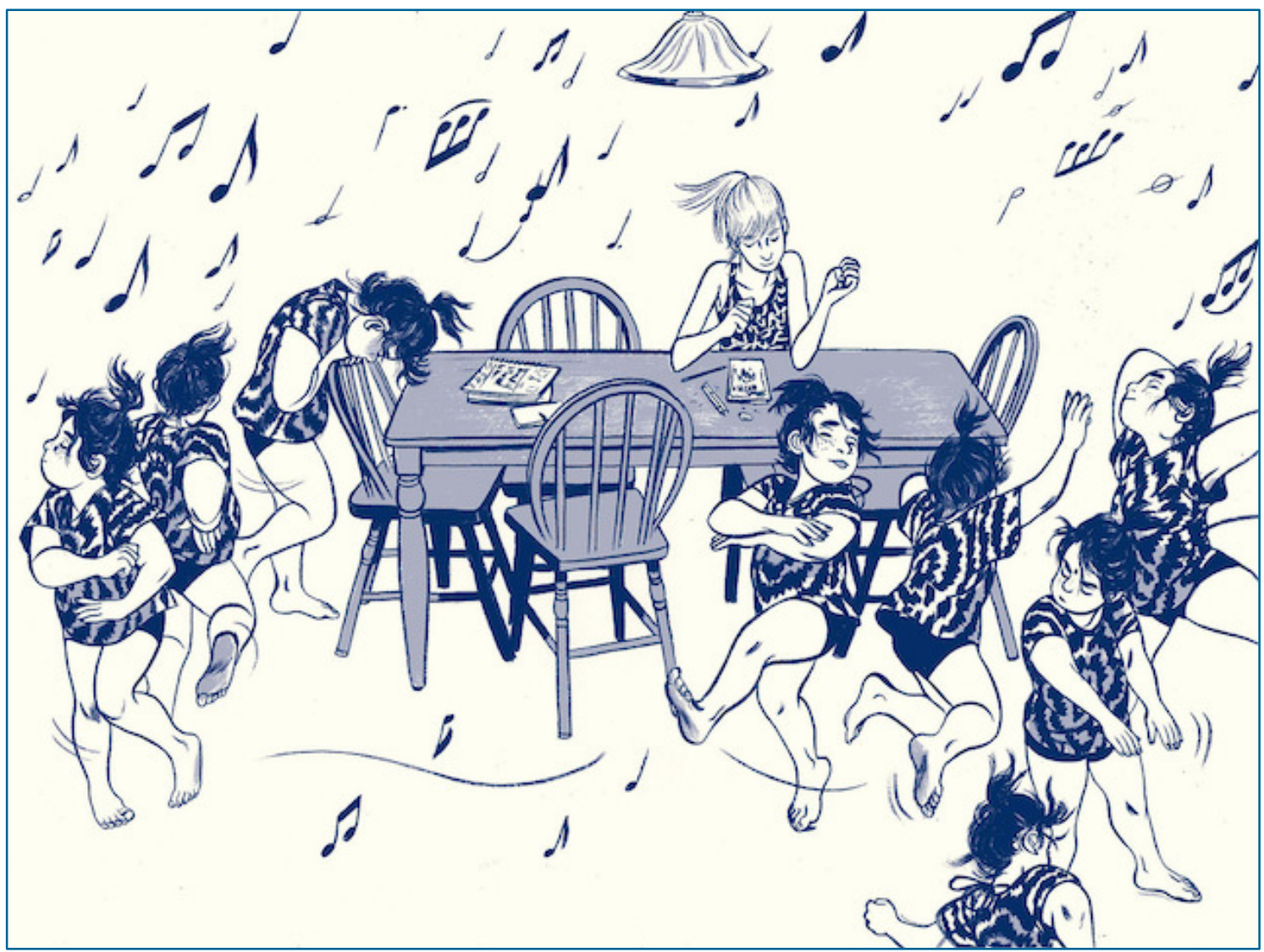

Figure 1. Winsnes, M. (2019). L'Âge des secrets. Paris: Sarbacane, p. 12.

Similarly, in L'Âge des secrets the two female protagonists are depicted being interested in new games or activities that differ from typically children's interests: they start having love stories, slight sexual interests, they explore their gender identity and their femininity both physically and psychologically. However, Hanna appears to be a little girl, as compared to her cousin, who clearly wishes to become a woman as soon as possible. For example, Siv wishes her breasts to start growing, constantly monitoring her physical changes excitedly.

Blue is the warmest colour deals with topics such as the construction of female identity, sexual orientation, and marginalized sexualities (lesbian/bisexual identity in this specific case), offering an indepth analysis of two different models of adolescents and their opposite approach to life-struggles, doubts, passions, and desires. Reading her diary, Emma discovers Clementine's anxieties, fears, uncertainties, her doubts about her sexual orientation -Emma always thought she was heterosexual before meeting the blue-haired girl- her most intimate sexual desires, her pain when the love-story ends. In particular, the story dwells on the torments of the girl who explores her sexual orientation in relation to various issues, including the possibility of being a victim of homophobic violence. The 
graphic novel develops a long path toward self-understanding and acceptance, taking the risk of being one's own self. The graphic novel/diary explores

\section{[...] the adolescent girl's experience of taking risks in forming an adult identity that feels both satisfying and real. [The story] features a young woman consumed with discovering what love costs and what it is worth [...] also offers a glimpse of a young woman negotiating her fears and desires and opting to take the risk to find out (Miller, 2017, 40).}

Risk, according to Michelle Miller, is a typical and 'healthy' characteristic of the adolescent: taking risks is necessary to explore, to change; taking risks leads to awareness, surpassing social labels. However, cultural norms hold back the young protagonist and narrator: in a culture where homosexuality is generally linked to unhappiness, Clementine, in Blue is the Warmest Color, wonders if it is possible to combine her orientation with serenity. She would like to live an ordinary life, work in a school, be accepted by her family, but many difficulties lie ahead, so much so that she repeatedly calls herself "happy but anxious". On the contrary, Emma is portrayed as a character who makes her sexual orientation her strength: "Emma is able, through her queerness, to form a community. Her queerness becomes not only her sexuality, but also the grounds upon which she builds a satisfying adult identity" (Miller, 2017, 44).

\subsection{Change and loneliness}

Change is one of the key issues in the works under study and it often relates to loneliness. Books on and for adolescents usually focus on moments of passage such as the summer or moving from one place to another, which metaphorically relates to adolescent conditions. Readers will often find a constant presence of silence, a constant lack of written words to allow the evocative power of some images to prevail; in this way, the sense of loneliness or inability to express certain emotions that typically characterise adolescence is emphasized even without the help of literary forms.

In This one summer, the story takes place, as the title suggests, in summer, a moment of passage between two school years. In this context, the numerous fears about becoming adults are silently illustrated. For example, Windy has to face her parents' divorce, an issue that forces her to deal with adult problems, to be constantly gloomy, thoughtful, and frightened. Summer is spent at the seaside, and the sea is shown as a place of solitude, where Windy can swim and get lost in her own thoughts, a place where she can isolate herself from the world and explore her intimate feelings, discovering her dreams and needs. An interesting fact is that the sea is perceived by the two girls as an opposite setting: if Rose loves to swim and have fun, Windy seems to prefer to float on the edge of the water and to alienate herself. 
In the same vein, in L'Âge des secrets, Siv changes her attitude. For example, encouraged by her new group of friends, she starts lying to her parents in order to spend the night out with her peers. Hanna, her long-lasting best friend, appears to be in a different phase of her life, still anchored to childhood: she feels out of place, she isolates herself as she cannot understand her friend's new behaviour. Siv goes out with older friends, dreams to have a love story, and her innocent behaviour turns into a more aggressive and wilder attitude. So, Hanna does not feel part of this new adult-like group and starts to silently break up with Siv. Siv is changing, but Hanna probably wishes to remain a little girl, or to wait to be effectively ready to start wishing for teenage adventures. The graphic novel cleverly mixes elements of childhood, for example playing in a treehouse, and adolescence, for instance smoking or dealing with opposite sex peers, illustrating the difficulties of growing up, with or without friends (Figure 2).

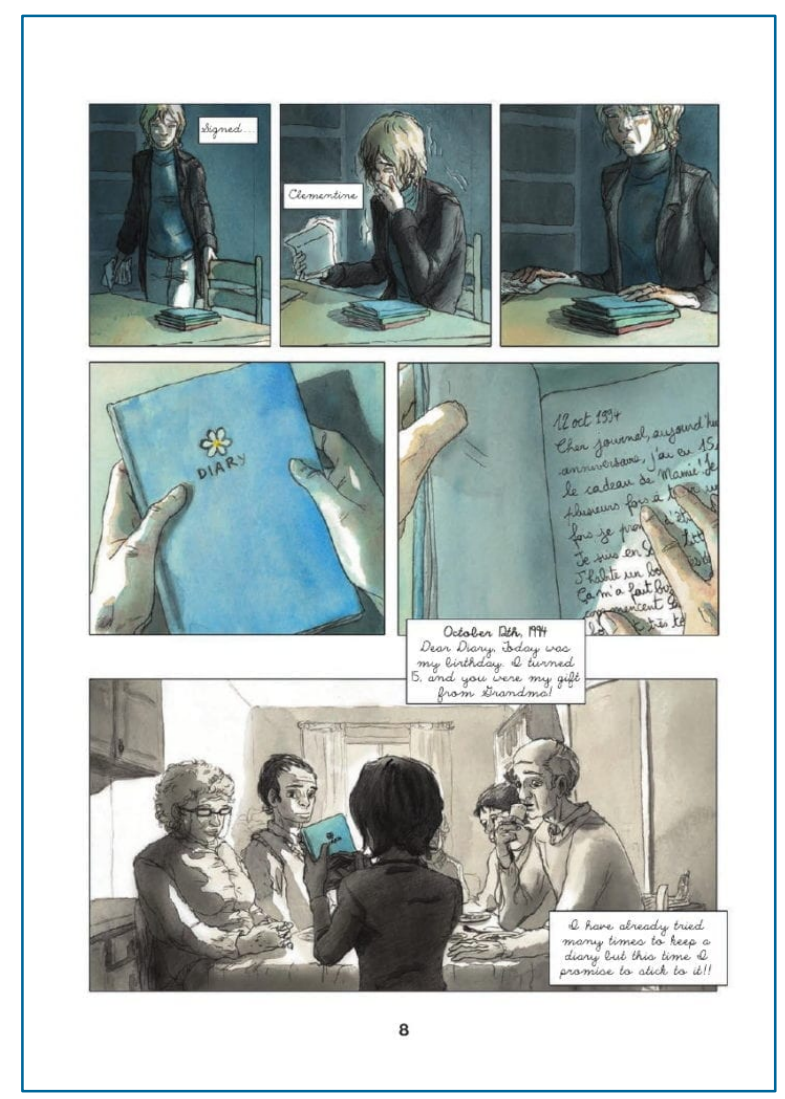

Figure 2. Maroh, J. (2017). Blue is the warmest colour. Vancouver: Arsenal Pulp, p. 8.

Loneliness is one of the most developed topics in this literature: adolescents or young adults are often portrayed alone. In Blankets, the author creates huge spaces of silence, of images that manage to convey, through snowy landscapes or portraits of the young protagonist, a sense of light loneliness 
and melancholy that occurs during his growth. The boy is changing and entering into adulthood, and he takes this step alone, relying on his own strength (Figure 3).

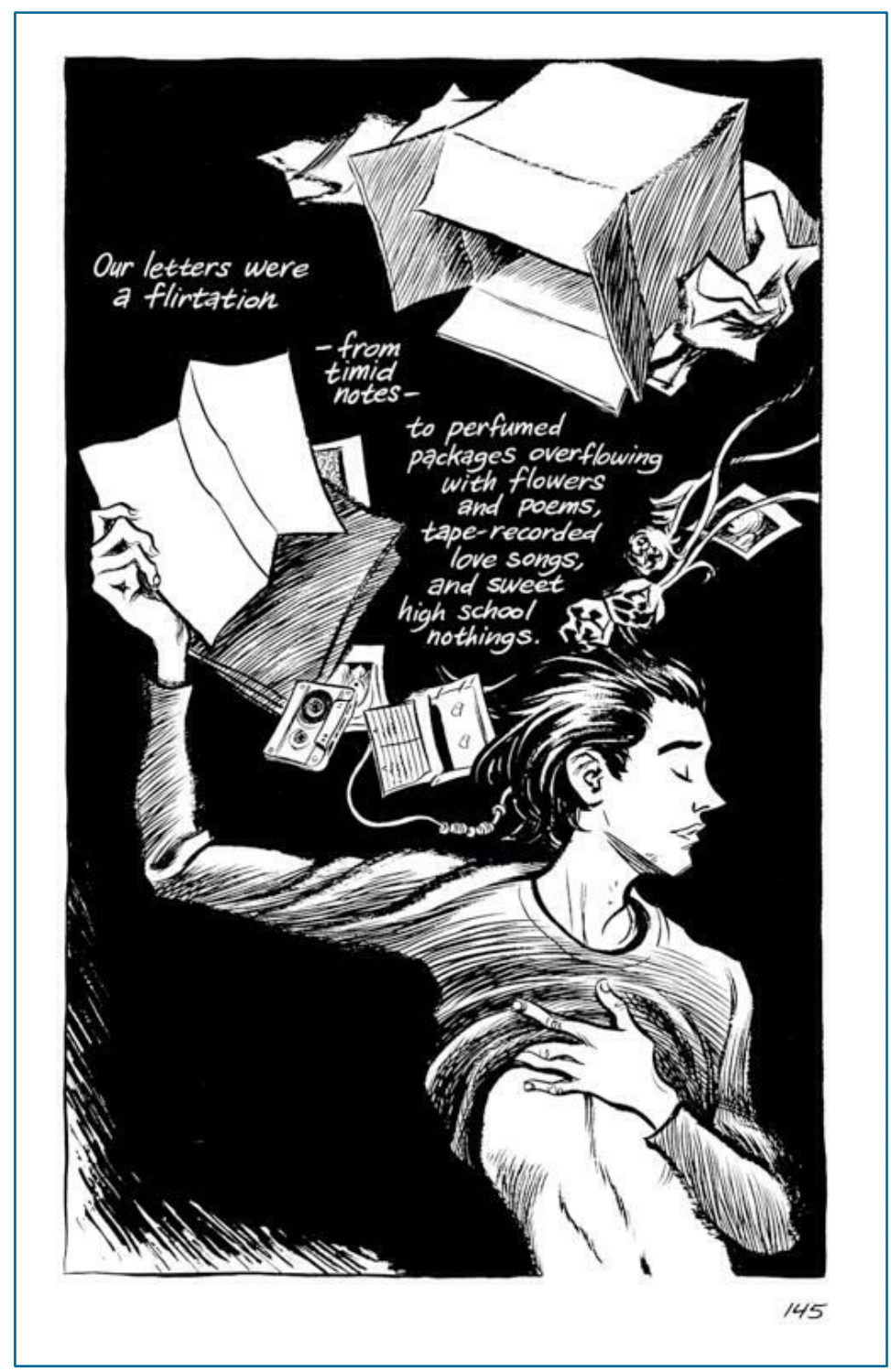

Figure 3. Thompson, C. (2017). Blankets. London: Faber and Faber, p. 145.

Considering Forget my name, the key to the author's success is simple: Zerocalcare brilliantly depicts the torments and dreams of several generations, capturing the instability exemplified through the autobiographical narrative which is fun and simultaneously pungent and politically aligned. His stories are full of anger and discontent during a long period of transition into adulthood, but the author does not usually forget (self-)irony to portray this feeling. So, growing up -in this case related to young adults dealing with 'adult' issues- is depicted as a precarious life-phase when constant comparison with their peers is at the root of insecurity and fear of becoming an adult. Again, despite the many relationships presented in the graphic novel, the key moments of the plot show the protagonist alone, 
facing his own troubles and thoughts. For instance, the protagonist overthinks his grandmother's death while lying on his bed, alone in the dark (Figure 4).

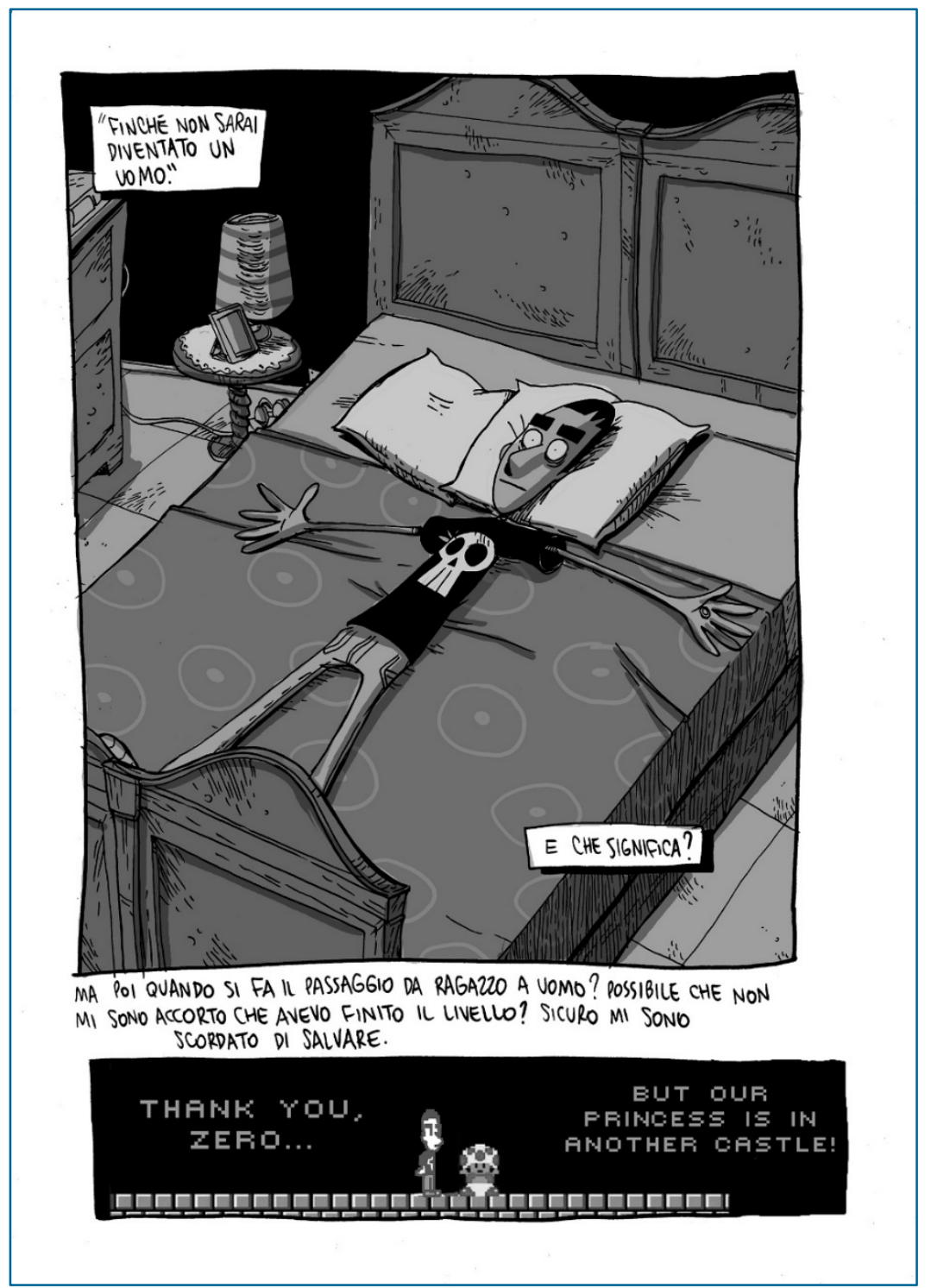

Figure 4. Thompson, C. (2017). Blankets. London: Faber and Faber, p. 145.

Furthermore, growth and change often provide a continuous desire to explore the world outside of one's own knowledge: these stories tell the (ordinary) lives of boys and girls who want to break the rules, crave to go beyond limits imposed by family and society in order to experience the world and, consequently, to know and understand their feelings, hopes and fears. So, the journey becomes an element of self-discovery, training, and tough confrontation (Ulivieri \& Pace, 2012): leaving -physically or metaphorically- home, the family nest, the known, teenagers and young adults deal with new issues, demonstrate their strengths, follow their intimate desires and, finally, better understand their roots and their future path without being guided by adult figures. 


\subsection{Colours}

Colours play a central role as they set the dominant mood of the story or of a particular section of the story, adding depth to the narrative and encouraging specific feelings (McCloud, 2000, 190; Calabrese, 2017, 72-76). In This one summer, figures are characterised by a simple style and a limited set of colours that develops around different shades of blue. This choice does not diminish the feelings evoked during the narration, but figures amplify them through a hue that can perfectly convey the sense of loneliness and incomprehension often experienced by the protagonists. Blue is the warmest colour chooses blue as its main chromatic tone, too, related in this case to black and white or pastel colour settings (Figure $5)$.

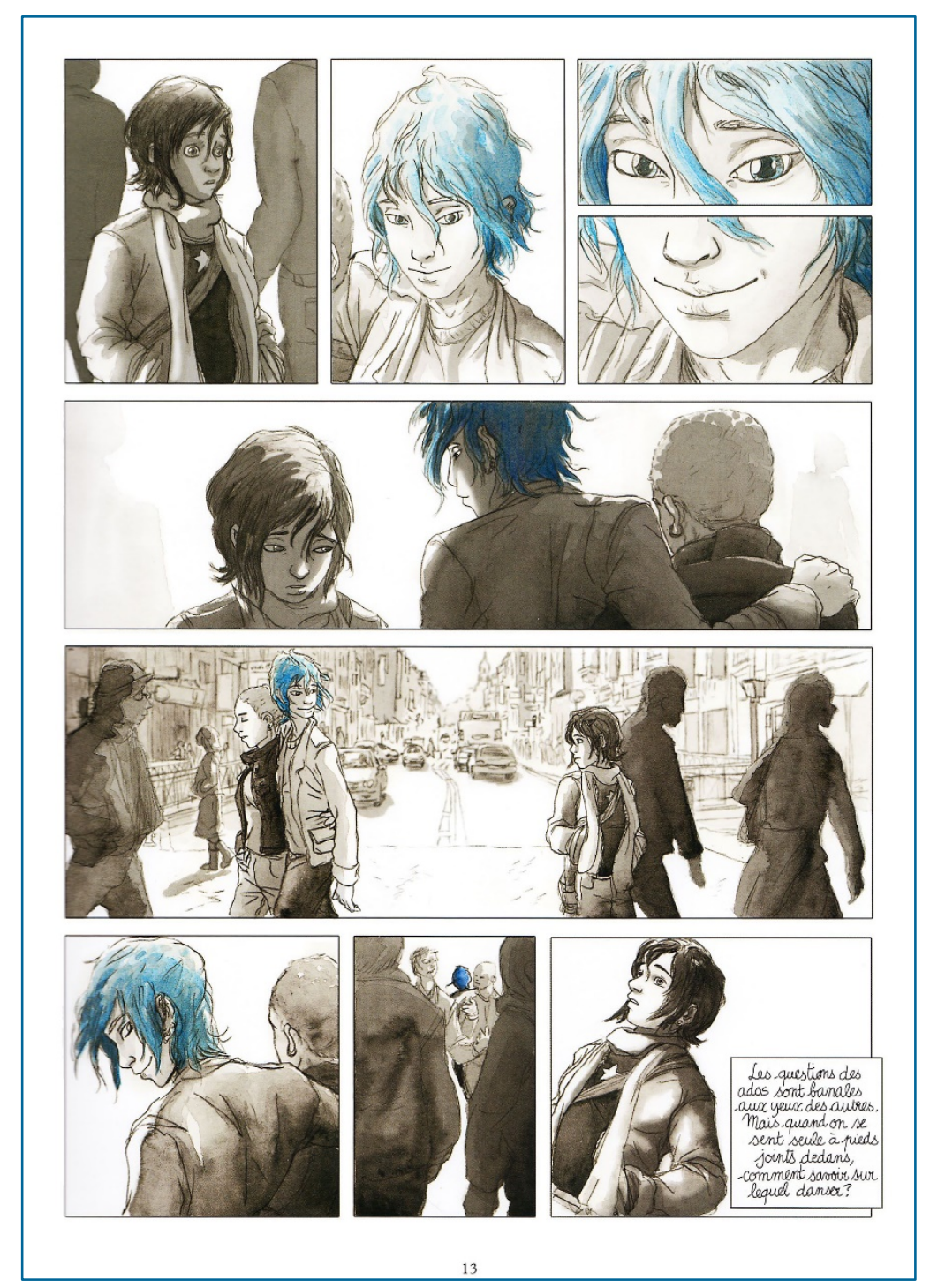

Figure 5. Maroh, J. (2017). Blue is the warmest colour. Arsenal Pulp, p. 13.

L'Âge des secrets, through illustrations characterised by light colours and simple features, offers an overview of how a female goes through the process of growing and self-discovery, focusing on one of the most delicate phases that characterise adolescence: pre-adolescence and those first steps that 
lead to a remarkable personal transformation. These two works, Blue is the warmest colour and L'Âge des secrets use light tones and create a hushed atmosphere through the use of colour.

In addition, in Forget my name and Blankets images offer powerful visual metaphors that portray the protagonist in a phase of change and self-discovery through the use of specific colours: black and white. A choice that manages to capture different nuances of the characters' growth, where black or white prevail one over the other on different pages. Again, in Blankets the colour blue creates a quiet atmosphere on the cover of the book, where the colour evokes silent, snowy spaces, setting the mood for the storytelling. Moreover, as pointed out by Stevens in his analysis of Blankets, the use of shadows also provides further metaphorical meanings, offering a new perspective on Craig's identity (Stevens, 2010). Thus, readers, observing silently the book's powerful images, enter the protagonist's intimacy and accompany him on his way towards growth and self-discovery interspersed with obstacles and satisfaction (Stevens, 2010; Peñalba García, 2015).

\subsection{Literary and stylistic choices: narrators, perspective, voices}

The literary approaches and themes selected to outline adolescence in this medium seem to present recurrent trends. One of the most interesting elements of this literary form is the particular approach adopted by authors and illustrators: generally, these books do not seek to impose themselves as models, offering characters that must be imitated by young readers. On the contrary, the purpose of these works is usually to represent the young target audience, and not to model and mould it according to precise standards. This refined and important stylistic choice may encourage readers to feel directly involved and never judged during the reading process, which never becomes invasive or judgmental. In fact, the graphic novels promote the adolescent's point of view; the protagonists or, in certain cases, the first-person narrators are frequently teenagers or young adults. For example, in Zerocalcare's Works, the first-person narrator and protagonist shares his feelings and fears while entering adulthood. The artist's works are characterised by some essential features: the constant presence of autobiographical events related to the character-narrator-artist; his immediately recognizable graphic style; the setting in the Rebibbia district, in Rome; the Roman slang that characterises the text; the imaginary participation of comic and cartoon characters from the '80s and the '90s (Ercolani, 2020, 29). These characteristics should lead to a very niche audience, yet his books are endowed with great "transgenerational ability" (Stefanelli, 2020, 27). Moreover, his works manage to create empathetic contact and identification even in readers that do not experience the specific social context described by the author. Indeed, over the years, Zerocalcare's comics have reached a wide international audience. As Stefanelli points out: "His stories [...] are not only fragments that give voice to the 
imaginary values of a generation. His work has generated concrete effects of remixing pop culture, Italian identity, youth condition and the story of our present times" ${ }^{4}(2020,24)$.

Similarly, but departing from a completely different cultural background (the US), the narrator in Blankets tells the story in first person and moves the plot along through numerous flashbacks and flashforwards. Since in both cases the young characters themselves relay the story, the narrative becomes more truthful and more participatory. Therefore, the narrative elicits the readers' perspective so as to encourage a wider empathetic contact and involvement. Both works could be considered as autobiographical fiction as they directly draw on the authors' experiences. When selecting an adult or young adult narrator to convey the story in first person, the use of flashback is very common: the characters revisit their past, critically observing some episodes during their childhood or adolescence. We therefore find teenagers who recall particular moments of their childhood, young adults who reflect on their adolescence, while often remain focused on the experiences they live in the moment depicted in the narrative. Finally, considering the language used by characters in all five books, in certain cases authors prefer a direct language that is reminiscent of oral tradition and everyday communication (Forget my name), while in others, authors attempt to strike a balance between a poetic style and a language that attempts to imitate young readers' language (Blankets, This one summer). In general, these works make an effort to adhere to reality and communicate a realistic view of the interaction between adolescents, even when employing a poetic tone.

\section{Conclusion}

Contemporary graphic novels are a cultural phenomenon, a valuable literary format that is opening up new possibilities in the field of young adult literature. Thanks to the synergy of images and words, the graphic novel turns out to be a medium that can easily develop complex stories while capturing the reader's attention and stimulating different reflections on multi-faceted themes. Among these, adolescence and identity formation seem to be one of the most popular subjects in this artistic form. Through realistic and frequently autobiographical narratives -often accompanied by fictional, imaginative elements or settings- graphic novels relate authentic life stories.

The present paper outlined some recurrent trends in contemporary graphic novels by authors from different countries (US, Canada, France, Norway, Italy). Despite different cultural backgrounds, the portrayal of adolescent is consistent as can be seen by the thematic, literary or aesthetic similarities

\footnotetext{
${ }^{4}$ Original Italian text: "I suoi racconti [...] non sono solo frammenti che danno voce alle coordinate di valori immaginari di una generazione. II suo lavoro ha generato effetti concreti di rimescolamento tra cultura Pop, identità italiana, condizione giovanile e racconto del presente".
} 
found in these works. Graphic novels on adolescence and young adulthood present this life phase as universal, addressing issues such as love and family relationships, friendship, growth, bodily transformations and awareness regarding sexuality and identity. These issues are presented by a nonjudgmental narrator who does not wish to present specific models to imitate, but rather to represent real dynamics and portrayals of adolescence. Adolescence and young adulthood are not described as idyllic life phases, but graphic novels on the subject specifically focus on young adult and teenagers' fears, problems, anxieties, so as to give a faithful and realistic representation of contemporary teenage identities.

\section{References}

Abbott, M. A. \& Tarbox, G. A. (eds.) (2017). Graphic novels for children and young adults: A collection of critical essays. Univ. Press of Mississippi.

Baetens, J. \& Frey, H. (2014). The graphic novel: An introduction. Cambridge University Press.

Barone, P. (2009). Pedagogia dell'adolescenza. Guerini Scientifica.

Barsotti, S. \& Cantatore, L. (eds.) (2019). Letteratura per l'infanzia. Forme, temi e simboli del contemporaneo. Carocci.

Beseghi, E. (2017). La letteratura per l'infanzia come serbatoio dell'immaginario. In

Bertagna, G. \& Ulivieri, S. (eds.), La ricerca pedagogica nell'Italia contemporanea (pp. 244-248). Studium.

Beseghi, E. (ed.) (1987). Ombre rosa. Le bambine tra libri, fumetti e altri media. Lisciani \& Giunti.

Bishop, R. S. (1990). Mirrors, Windows and Sliding Glass Doors. In Perspectives: Choosing and Using Books for the Classroom, 6(3), 9-11.

Calabrese, S. (2017). Che cos'è il graphic novel? Carocci.

Cambi, F. (2019). Formarsi tra i romanzi. Studi sulla formazione, 22(1), 125-135.

Dallari, M. and Farnè, R. (eds.) (1977). Scuola e fumetto. Proposte per l'introduzione nella scuola del linguaggio dei comics. Emme Edizioni.

Dal Lago, A. and Giordano, S. (2006). Mercanti d'aura. Logiche dell'arte contemporanea. il Mulino.

Detti, E. (1984). II fumetto tra cultura e scuola. La Nuova Italia.

Eisner, W. (2000). Comics and Sequential Art. W. W. Norton and Company.

Ercolani, A. (2020). II segreto di Zerocalcare. In Scarpa, L. (ed.), Leggere Zerocalcare. Guida ai fumetti di un antieroe (pp. 29-43). ComicOut.

Faeti, A. (1983). La "camera" dei bambini: cinema, mass media, fumetti, educazione. Edizioni Dedalo.

Forni, D. (2020a). Riflettere sul bullismo attraverso i graphic novel. Violenza e realismo letterario per adolescenti. Civitas Educationis. Education, Politics, and Culture, 9(1), 181-197.

Forni, D. (2020b). Children's Literature across Media: Film and Theatre Adaptations of Roald Dahl's 'Charlie and the Chocolate Factory'. ETS.

Garrison, K. L. (2020). Growing Up Graphically: Coming-of-Age Issues in Graphic Novels. Knowledge Quest, 48(5), 8-14.

Greco, C. (2014). Graphic novel: confini e forme inedite nel sistema attuale dei generi. Edizioni Nuova Cultura. 
Nodelman, P. (1990). Words about pictures. The narrative art of children's picture books. Georgia: University of Georgia Press.

Mancaniello, M. R. (2018). Per una pedagogia dell'adolescenza. Società complessa e paesaggi della metamorfosi identitaria. PensaMultimedia.

Marone, G. (2005). Il fumetto tra Pedagogia e racconto. Roma: Tunuè.

McCloud, S. (1993). Understanding comics: The invisible art. Mass.

Miller, M. (2017). Theorizing “The Plunge”. (Queer) Girls' Adolescence, Risk, and Subjectivity in Blue is the Warmest Color. Girlhood Studies, 10(1), 39-54.

Moretti, F. (1999). I/ romanzo di formazione. Einaudi.

Peñalba García, M. (2015). Writing the Self, Drawing the Self: Identity and Self-Reflexivity in Craig Thompson's Graphic Memoir Blankets. Cultura, Lenguaje y Representación, 14, 155-180.

Stein, D. \& Thon, J. N. (eds.) (2013). From comic strips to graphic novels. Contribution to the Theory and History of Graphic Narrative. de Gruyter publications.

Stefanelli, M. (2020). Zerocalcare, la sfera pubblica e del fumetto con risorsa. In Scarpa, L. (ed.), Leggere Zerocalcare. Guida ai fumetti di un antieroe (pp. 23-28). ComicOut.

Stevens, B. (2010). The Beautiful Ambiguity of Blankets: Comics Representation and Religious Art. ImageTexT: Interdisciplinary Comics Studies, 5(1), http://imagetext.english.ufl.edu/archives/v5_1/stevens/

Strazzulla, G. (1977). Fumetti di ieri e di oggi. Cappelli Editore.

Trisciuzzi, M. T. (2017). Image and imagination in education. Visual narrative through children's literature. Ricerche di Pedagogia e Didattica, 12(3), 69-81.

Trisciuzzi, M. T. (ed.) (2020). Sentieri tra i Classici. Vecchie e nuove proposte della Letteratura per l'infanzia e per ragazzi. PensaMultimedia.

Ulivieri, S. \& Pace, R. (eds.) (2012). Il viaggio al femminile come itinerario di formazione identitaria. FrancoAngeli.

\section{Literary works}

Maroh, J. (2017). Blue is the warmest colour. Arsenal Pulp.

Tamaki, J. \& Tamaki, M. (2014). This one summer. First Second.

Thompson, C. (2017). Blankets. Faber and Faber.

Winsnes, M. (2019). L'Âge des secrets. Sarbacane.

Zerocalcare (2015). Forget my name. Bao Publishing.

How to cite this paper:

Forni, D. (2021). Literature for self-discovery. Looking into adolescence through graphic novels. Journal of Literary Education, (5), 124-143. https://doi.org/10.7203/JLE.5.20429 